Research Article

\title{
Effect of Friction Stir Processing on Gas Tungsten Arc-Welded and Friction Stir-Welded 5083-H111 Aluminium Alloy Joints
}

\author{
Sipokazi Mabuwa (iD and Velaphi Msomi \\ Cape Peninsula University of Technology, Mechanical Engineering Department, 7535 Cape Town, South Africa \\ Correspondence should be addressed to Sipokazi Mabuwa; sipokazimabuwa@gmail.com
}

Received 23 July 2019; Revised 25 September 2019; Accepted 9 October 2019; Published 29 October 2019

Academic Editor: Marián Palcut

Copyright ( 2019 Sipokazi Mabuwa and Velaphi Msomi. This is an open access article distributed under the Creative Commons Attribution License, which permits unrestricted use, distribution, and reproduction in any medium, provided the original work is properly cited.

\begin{abstract}
This paper presents the analysis of the friction stir-processed aluminium alloy 5083-H111 gas tungsten arc-welded and friction stir-welded joints. The comparative analysis was performed on the processed and unprocessed gas tungsten arc-welded and friction stir-welded joints of similar aluminium alloy 5083-H111. The results showed a clear distinction between the friction stir processed joints and unprocessed joints. There is a good correlation observed between the microstructural results and the tensile results. Ultrafine grain sizes of $4.62 \mu \mathrm{m}$ and $7.177 \mu \mathrm{m}$ were observed on the microstructure of the friction stir-processed friction stir-welded and gas tungsten arc-welded joints. The ultimate tensile strength for friction stir-welded and gas tungsten arc-welded before friction stir processing was 153.75 and $262.083 \mathrm{MPa}$, respectively. The ultimate tensile strength for friction stir processed friction stir-welded joint was $303.153 \mathrm{MPa}$ and gas tungsten arc-welded joints one was $249.917 \mathrm{MPa}$. The microhardness values for the unprocessed friction stir-welded and gas tungsten arc-welded joints were both approximately $87 \mathrm{HV}$, while those of the friction stir-processed ones were 86.5 and $86 \mathrm{HV}$, respectively. The application of friction stir processing transformed the gas tungsten arc morphology from brittle to ductile dimples and reduced the ductile dimple size of the unprocessed friction stirwelded joints from the range of $4.90-38.33 \mu \mathrm{m}$ to $3.35-15.59 \mu \mathrm{m}$.
\end{abstract}

\section{Introduction}

The materials-processing technology is as old as civilization. England started machine automation for forming, shaping, and cutting in the 18th to the 19th century. Since then, materials-processing methods, techniques, and machinery have grown numerously [1]. The material processing was introduced as the method of improving the material properties to suit a specific purpose. The selection of material with specific properties is the key parameter in many manufacturing industries like aircraft industry, automotive industry, and hydrovehicle industry [2]. Aluminium is known to be light in weight and a good corrosion-resistant material. These features have brought attention towards this material such that it became the best material suitable for building the aircraft structures, ship structures, and automotive components. The other benefit of using aluminium is that its weight lightness contributes to the reduction of power consumption [3]. The 5083-H111 aluminium alloy (AA) from the wrought alloy $5 \mathrm{xxx}$ series was selected to be utilized in this paper. Generally, the $5 \mathrm{xxx}$ offer outstanding corrosion resistance, making them suitable for marine applications. The 5083 alloy has the highest strength of the nonheat treatable alloys but is not recommended for use in temperatures exceeding $65^{\circ} \mathrm{C}$. The alloy is highly resistant to be attacked by both seawater and industrial chemical environments [4]. Alloy 5083 also retains exceptional strength after welding in comparison to other alloys. Aluminium alloys are produced in different forms which mean different manufacturing or joining methods are required, i.e., welding and riveting. Welding is known to be the most used metal joining method. Welding is also divided into different types, i.e., gas metal arc welding (GMAW), gas tungsten arc welding (GTAW), friction welding (FW), friction stir welding (FSW), and laser welding. 
The GTAW method has been the preferred method for welding aluminium alloys due to its cleanliness, but recently, the preference has shifted towards FSW. This shift is due to the fact that FSW is clean and does not produce any gas to the atmosphere, hence considered as green technology as well as fusion welding techniques such as arc welding result in several problems, namely, porosity formation, loss of strength, and cracking particularly in high strength Al-alloys [5-9]. Friction stir welding (FSW) is a solid-state welding method, which is invented by the welding institute (TWI) and has been well demonstrated particularly suited for the joining of aluminium alloys [10-16]. This then suggests that there are numerous progressive developments that are trying to optimize this new technology (FSW). This includes the introduction of friction stir processing (FSP) technology. FSP is another new technique being used to modify the microstructure of metals [17-21]. The FSP technique works similar to FSW but FSP does not join the materials instead it modifies the material's microstructure through the pinned or pinless tool. Due to the frictional heat generated, the material undergoes severe plastic deformation, resulting in significant microstructural changes in the processed zone [22-25]. FSP generates three distinct microstructural zones in the processed area, namely, the nugget zone (NZ), thermomechanically affected zone (TMAZ), and heat-affected zone (HAZ) [26, 27]. The first work on FSP was reported by Mishra et al. [28] where FSP was used in enhancing the strain rate plasticity of 7075 aluminium alloy. Since then, FSP was employed to perform various modifications, and this includes the fabrication of surface composite.

Cast aluminium A206 was subjected to FSP with the purpose of modifying its microstructure. The results showed a significant reduction in grain size on the processed regions compared to the unprocessed regions of the plate. The microhardness for the processed regions was increased compared to the unprocessed regions. The processing of this material was also found to have contributed to the improvement of its tensile strength $[29,30]$. There are different types of parameters that are involved in FSP. This includes tool shape and geometry, welding speeds, and rotational speeds. The good combination of these parameters advocates the achievement of a good product. SSM 356 aluminium alloy was used to study the impact of welding and rotational speeds towards the mechanical properties of this material [31]. These speeds were varied with the purpose of obtaining the optimum combination. The rotational and travelling speeds of $1750 \mathrm{rpm}$ and $160 \mathrm{~mm} / \mathrm{min}$, respectively, were found to be optimal values in obtaining an improved result. A notable increase in microhardness and tensile strength of the processed region compared to the unprocessed one was reported. The microstructural analysis also showed homogeneity on the processed region compared to the unprocessed one [32]. The literature has shown some investigations on the influence of FSP on the microstructure and the tensile properties of AL-Si alloy [33]. Golafshani et al. [34] and Saini et al. [35] performed similar studies with the same alloy subjected to FSP. Process parameters used included tool tilted of angle $3^{\circ}$, while the rotational speed and welding speed were fixed at $1400 \mathrm{rpm}$ and $42 \mathrm{~mm} / \mathrm{min}$, respectively. There was a notable increase in ductility on the processed plates compared to the unprocessed one. The ultimate tensile strength (UTS) for the processed plates was found to be higher than those which were unprocessed. Similarly, FSP resulted in fine equiaxed grains improving the tensile properties of the processed alloys [36-38].

This paper reports the analysis of the mechanical properties of the processed friction stir-welded (FSWed) and gas tungsten arc-welded (GTAWed) AA5083-H111 joints. The processed joints are analyzed in comparison to the unprocessed welded joints. This study is performed so as to establish whether FSP technique can be used as a postprocessing method in improving the quality of the said welded joints. This topic was carefully chosen after noticing that there is little or no literature available on the friction stir processing of the GTAWed and FSWed joints; most literature studies have been focusing on the friction stir processing of single materials. The outcome of this paper will then give the engineers in the material processing industry an alternative for the enhancing of mechanical properties which will play a huge role in extending life span of welded structures.

\section{Materials and Methods}

The aluminium alloy 5083-H111 plate with a thickness of $6 \mathrm{~mm}$ was used in performing the experiments of this study. Eight rectangular specimens of $530 \mathrm{~mm}$ by $70 \mathrm{~mm}$ were cut from the supplied aluminium plate. Table 1 presents the chemical composition of the base metal (AA5083-H111). The dimensioned plates were welded together using FSW and GTAW techniques.

Friction stir welding was performed using a semiautomated milling machine. A nonconsumable tool made of high-carbon steel (H13) was used in fabricating the joints. The dimensions of the tool are shown in Figures 1(a) and 1(b). Figure 1(c) shows the image of the tool. The pin was positioned at the centre of the joint line with the purpose of enhancing material and grain refinement $[40,41]$. A singlepass welding procedure was used to fabricate the joints [22]. The welding parameters used for this study are presented in Table 2. The sample of the weld produced by FSW is shown in Figure 1(d).

The plates used in FSW are similar to the plates used for GTAW. The only difference was that the edges to be GTAWed had to be cut to a double V-groove as set out in ISO 9692. This was done so as to enhance the strength of the welding joint and also to minimize the weld distortion [42]. The sample of the GTAWed plate is shown in Figure 1(e). It should be noted that a ER5356 filler wire with a $2.4 \mathrm{~mm}$ diameter was used. Argon shielding gas was used to protect the weld pool from the dissolution of atmospheric gases [36]. Table 3 presents the GTAW parameters. All the welds produced by GTAW and FSW techniques were later friction stir processed.

The processing parameters used for FSP were similar to the ones used for FSW. Figure 2(a) shows the friction stir processing setup for the GTAWed joints, and Figure 2(b) shows the friction stir processing of the FSWed joints. The 
TABLE 1: Chemical composition of the base metal [39].

\begin{tabular}{lcccccccccc}
\hline Base metal & $\mathrm{Mg}$ & $\mathrm{Mn}$ & $\mathrm{Fe}$ & $\mathrm{Si}$ & $\mathrm{Cu}$ & $\mathrm{Cr}$ & $\mathrm{Zn}$ & $\mathrm{Ti}$ & $\mathrm{Zr}$ & $\mathrm{Al}$ \\
\hline AA5083-H111 & 4.254 & 0.525 & 0.259 & 0.980 & 0.346 & 0.113 & 0.103 & 0.019 & 0.002 & 93.31 \\
\hline
\end{tabular}

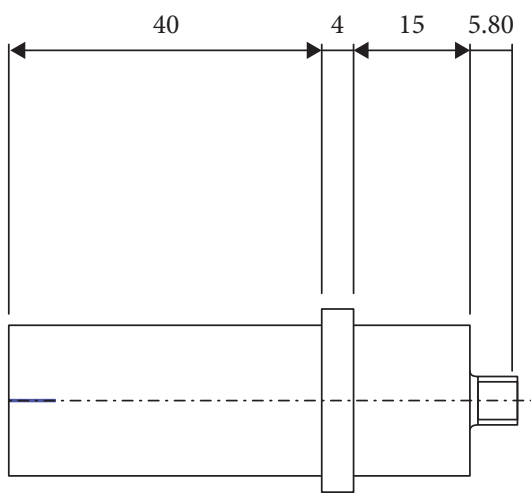

(a)

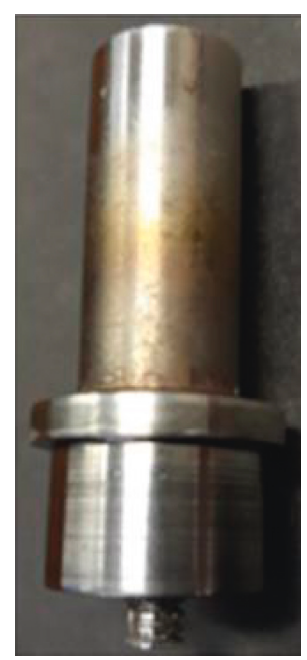

(c)

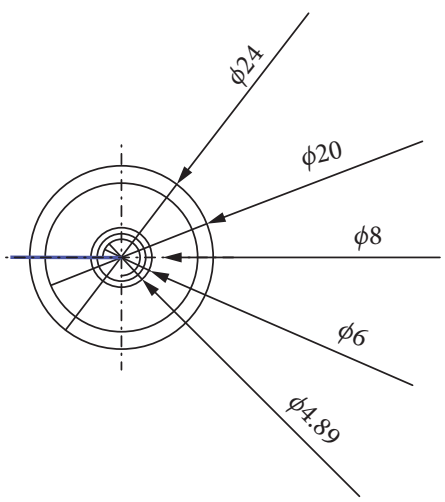

(b)

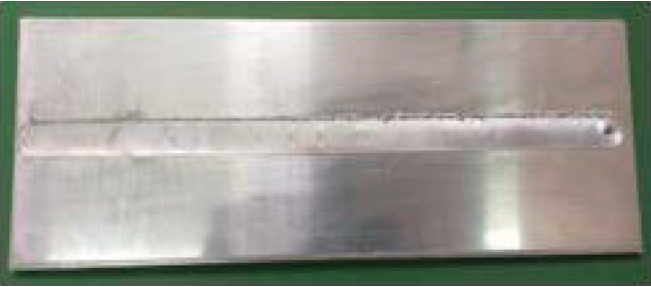

(d)

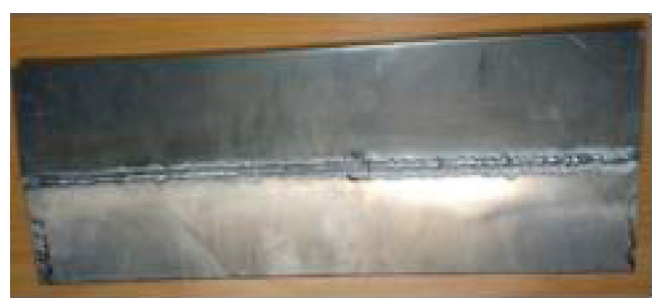

(e)

Figure 1: (a, b) Tool dimensions (in mm), (c) FSW/P Tool, (d) FSW joint, and (e) GTAWed plate.

TABLE 2: Friction stir welding parameters.

\begin{tabular}{lccc}
\hline Rotational speed $(\mathrm{rpm})$ & Travelling speed $(\mathrm{mm} / \mathrm{min})$ & Vertical force $(\mathrm{kN})$ & Tilt angle $\left({ }^{\circ}\right)$ \\
\hline 1000 & 30 & 4.5 & 2 \\
\hline
\end{tabular}

TABLE 3: GTAW parameters.

\begin{tabular}{lccc}
\hline Welding current $(\mathrm{A})$ & Shielding gas flowrate $(\mathrm{l} / \mathrm{min})$ & Voltage $(\mathrm{V})$ & Travel speed $(\mathrm{mm} / \mathrm{min})$ \\
\hline 200 & 15 & 16 & 150
\end{tabular}




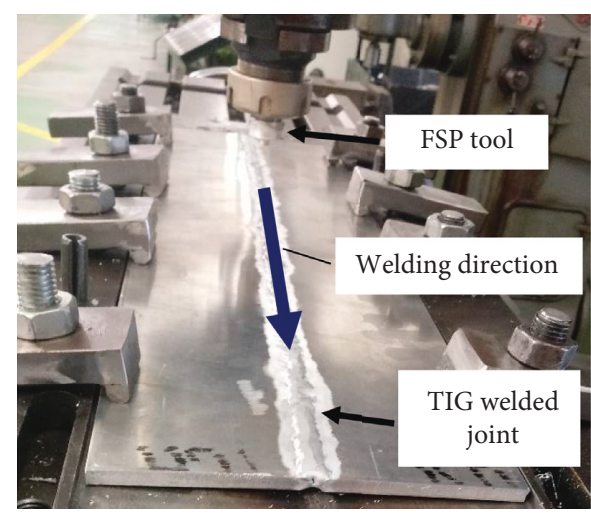

(a)

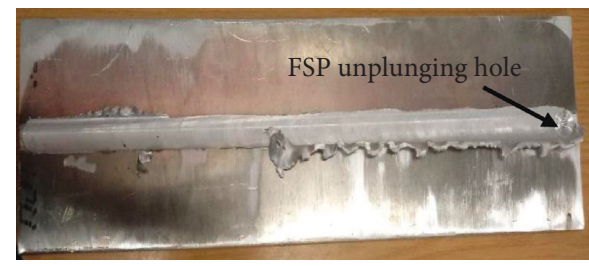

(c)

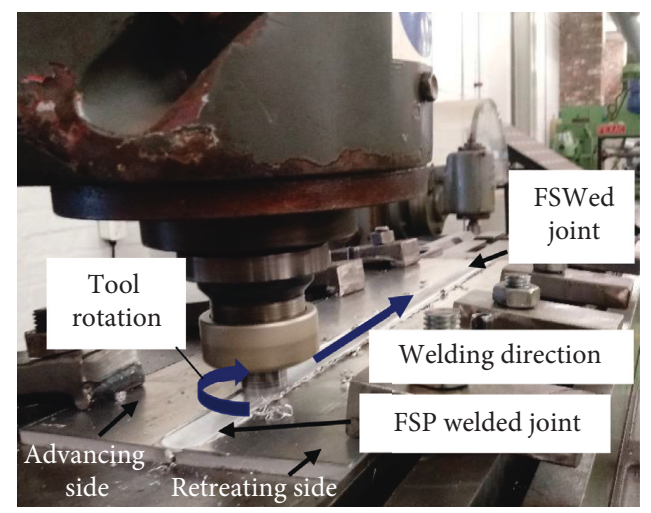

(b)

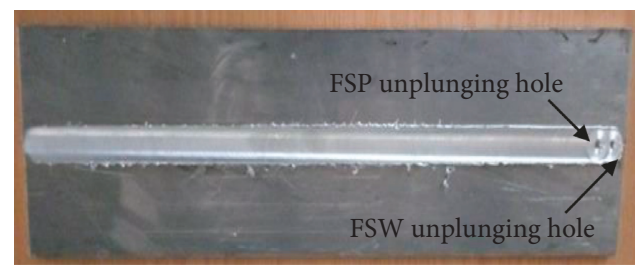

(d)

Figure 2: (a) Friction GTAWed joint, (b) FSP on FSWed joint, (c) sample of the processed GTAWed joint, and (d) sample of the processed FSWed joint.

single-pass FSP was used in processing the joints. The same tool used for FSW was also used for FSP. The use of FSP tools with pins have been used in previous studies [37, 38, 43-45]. Figure 2(c) shows the friction stir-processed GTAWed joint, and Figure 2(d) shows the friction stir-processed FSWed joint. The two end holes in Figure 2(d) depicts the hole left after FSW, and the second one is the hole left after FSP. FSP hole is the only hole that can be seen in Figure 2(c).

2.1. Experiments. The FSWed, GTAWed, and friction stirprocessed plates were cut for different tests. The waterjet cutting technique was used to cut the specimens, and this cutting technique was chosen because it does not involve heat and does not temper with mechanical properties during the cutting process. The tests performed on these specimens include tensile testing, microhardness, and microstructural analysis. The tensile tests were performed using the Hounsfield tensile testing machine. The ASTM-E8M-04 was used for specimen geometry and tensile testing. The specimen geometry used (dimensions in $\mathrm{mm}$ ) for tensile testing is shown in Figure 3(a). The tensile test parameters are presented in Table 4. The force versus extension data were logged, and the graphical representation of the logged data is presented under the Results section.

Vicker's microhardness tests were performed using microhardness testing machine with Vicker's scale. The ASTM E384-11 standard was used in performing microhardness testing. The tests were performed along the horizontal section of the welded joint specimen. The interval of $2 \mathrm{~mm}$ was used from the centre of the weld to either advancing or retreating side of the specimen. The load of $300 \mathrm{~g}$ and a dwell time of $15 \mathrm{~s}$ were used. The microstructural analysis was performed using a metallurgical microscope. Prior to the microstructural analysis, the specimens were cut according to sizes shown in Figure 3(b). The two lines in Figure 3(b) show where the welded area starts and ends. The cut specimens were mounted on Bakelite, hand polished, and etched. The etchant used was the sodium hydroxide $(\mathrm{NaOH})$ made of $2 \mathrm{~g}$ of $\mathrm{NaOH}$ and $100 \mathrm{ml}$ of distilled water. The etchant was poured on top of the specimen and immersed for $1 \mathrm{~min}$ for the preetch and $10 \mathrm{~min}$ for full etching.

It should be noted that there is a start location, middle location, and ending location in the friction stir-processed and the welded plates. So the three specimens were produced from the start, middle and the end of either welding or processing (see Figure 4). The specimen that was cut at the beginning of the plate was marked with A, while B symbolized the middle position and $\mathrm{C}$ was the end position of the plate. For unprocessed specimen labelling, formats $\mathrm{A}, \mathrm{B}$, and $\mathrm{C}$ were used while A2, B2, and C2 symbolized friction stir-processed specimens. This presentation was followed in all the tests that were performed. The test results are presented and discussed in the next section.

\section{Results and Discussion}

This section gives a detailed discussion of the results that were obtained from different test techniques. The results obtained include macrostructure, microstructure, tensile tests, microhardness, and fracture surface morphology.

3.1. Macrostructure. Figure 5 shows the macrostructure of the unprocessed and friction stir-processed FSWed and GTAWed joints. Figure 5(a) shows macrostructure of 


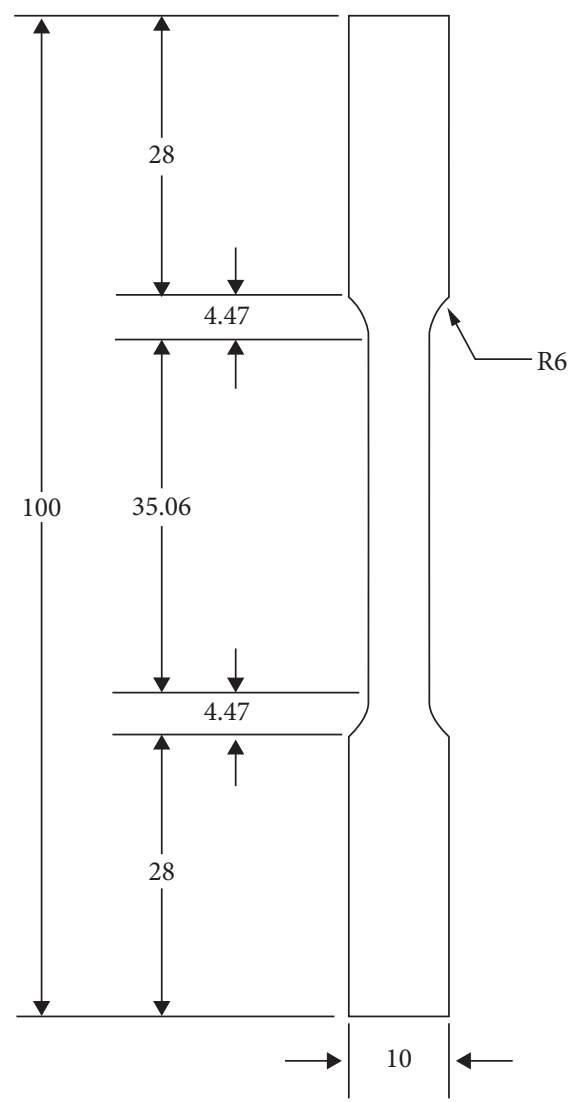

(a)

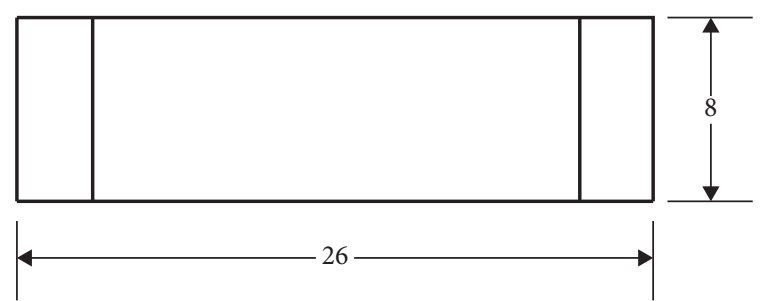

(b)

Figure 3: (a) Tensile test specimen and (b) microstructure and microhardness test specimen.

TABLE 4: Tensile test parameters.

\begin{tabular}{lccc}
\hline Speed $(\mathrm{mm} / \mathrm{min})$ & Extension range $(\mathrm{mm})$ & Load range $(\mathrm{kN})$ & Load cell $(\mathrm{kN})$ \\
\hline 1 & $0-10$ & $0-10$ & 50 \\
\hline
\end{tabular}

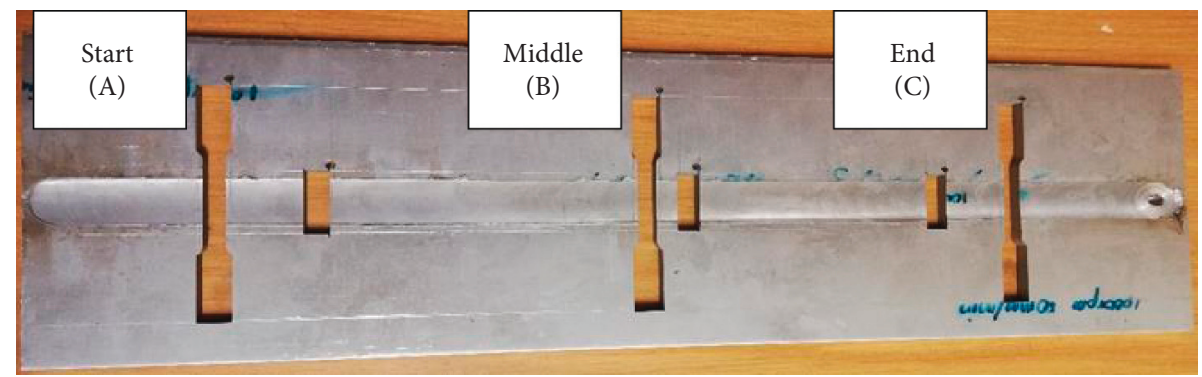

FIGURE 4: Specimen regions.

AA5083-H111 BM. The AS is the advancing side and RS is the retreating side in Figures 5(b) to 5(e). Figure 5(b) shows the surface of the unprocessed GTAWed joints. The surface consists of few pores that are appearing on the welded joint with no visible cracks. It is assumed that the distinction between the welded plates and the filler together with the presence of pores on the joint contributes towards the joint weakness [36]. Figure 5(c) shows the friction stir-processed
GTAWed joint, where the onion ring structure is present and a small portion of the unprocessed GTAWed structure is also appearing on the edges of the welded joint. There are no pores and cracks observed from the figure. The macrostructure of the unprocessed FSWed joint is shown in Figure 5(d). The joint shows bonding without defects. Figure 5(e) shows the friction stir-processed FSWed joint macrostructure. The unprocessed FSWed and the friction 


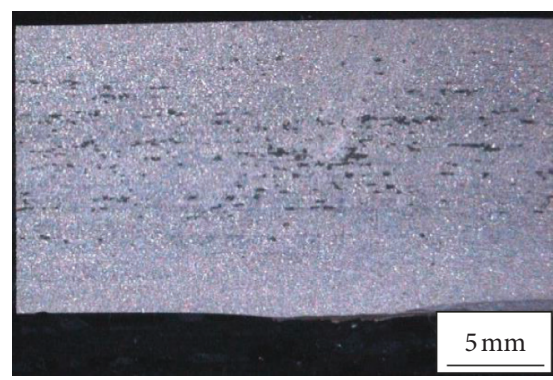

(a)

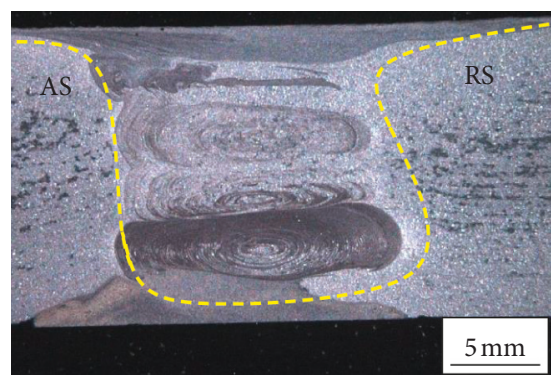

(c)

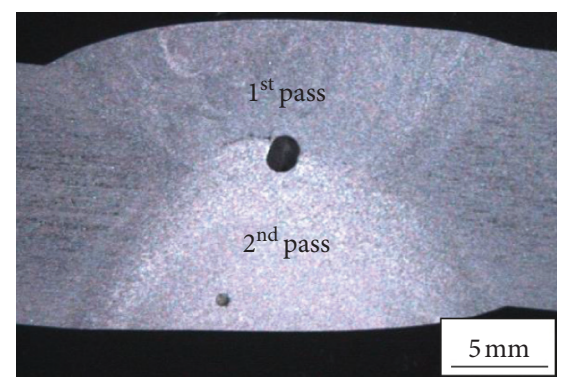

(b)

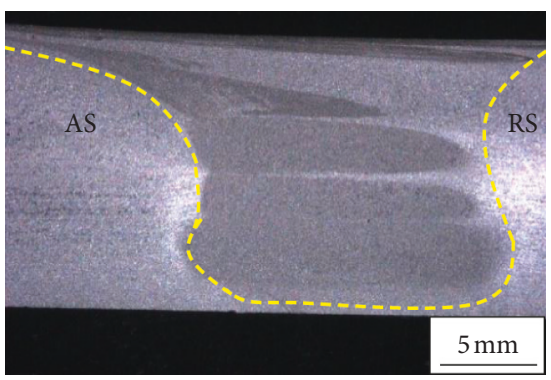

(d)

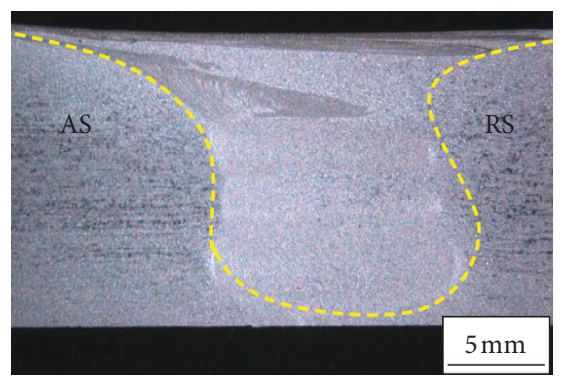

(e)

Figure 5: (a) Base metal (AA5083-H111), (b) unprocessed GTAWed 5083-H111 alloy, (c) friction stir-processed GTAWed alloy macrostructure, (d) unprocessed FSWed joint, and (e) friction stir-processed FSWed onion ring.

stir-processed FSWed reveal onion ring microstructure that is also observed on the friction stir-processed GTAW. There is a normal feature of the banded structure [46]. The visibility of the onion ring feature suggests a good bonding or improved joint quality [47-49].

3.2. Microstructure. The microstructure of the stir zones of unprocessed and friction stir-processed FSWed and GTAWed joints is presented in Figure 6. Figure 6(a) presents the microstructure of the base metal (AA5083-H111) comprising of the coarse grain structures. Dark dendrites with fine precipitates of $\mathrm{Mg}_{3} \mathrm{Al}_{2}$ were noted in the micrograph of the unprocessed GTAWed joint depicted in Figure 6(b), and this is a common phenomenon with filler wire ER 5356 microstructure [50]. The application of FSP on the GTAWed joints resulted in very fine grain structure with distinguished boundary layers in comparison to the unprocessed one (see Figure 6(c)). The unprocessed FSWed micrograph in Figure 6(d) shows the uniform arrangement with fine grains. Ultrafine grains with uniform arrangement is also noticed on friction stir-processed FSW. This arrangement was caused by the dynamic recrystallization (DRX) during the friction stir processing. The same behaviour was noted on the friction stir-processed GTAWed joints which resulted in very fine equiaxed grains on the stir zone [51-53].

Three measurements were performed on the stir zones of the welded joints where 1 stands for the beginning, 2 centre, and 3 towards the end of the stir zone in Table 5. Unprocessed GTAWed and FSWed grain sizes were found to be bigger than the friction stir-processed ones. However, the unprocessed joint grain sizes are smaller compared to the base material. The average grain sizes for the unprocessed FSWed joint is $10 \mu \mathrm{m}$ while an average of $7 \mu \mathrm{m}$ corresponds with the friction stir-processed FSWed joint. A similar trend is also noticed with the unprocessed and friction stir-processed GTAWed joint. The microstructural results correlate with the tensile properties, hence the ductile fracture. The grain refinement of the friction stir-processed welded joints is in agreement with the Hall-Petch relation which predicts that the grain size decreases with an increase in the UTS. The microstructural smaller grain size resulted in a higher hardness level of the welded region $[49,54]$. Additional grain 


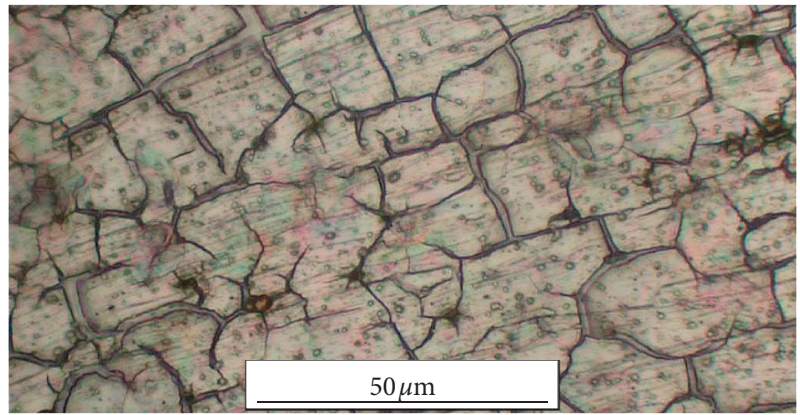

(a)

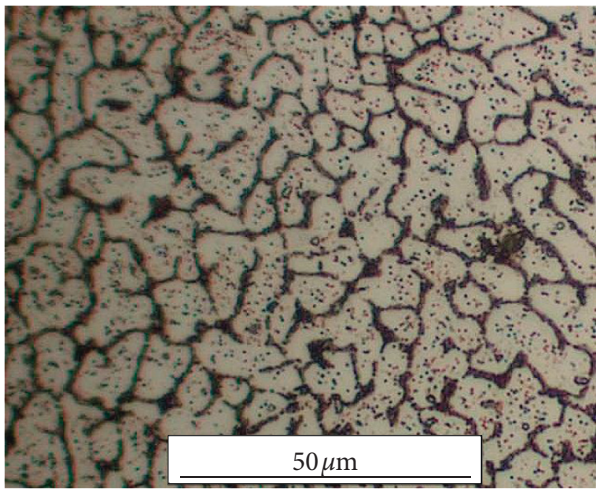

(c)

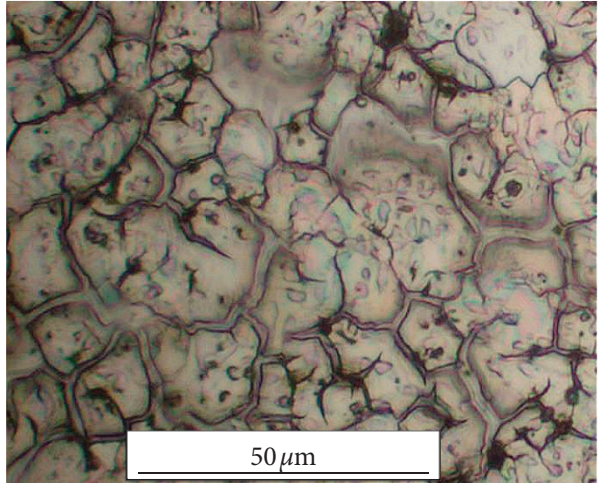

(b)

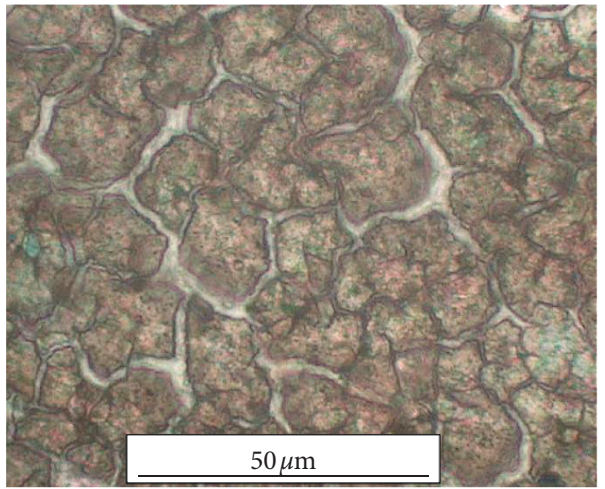

(d)

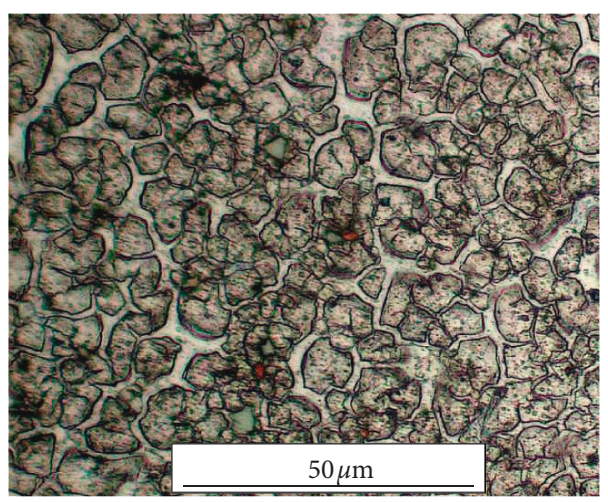

(e)

FIGURE 6: Optical micrographs of the NZ regions at $50 \mu \mathrm{m}$ scale (objective 50x) (a) base material, (b) unprocessed GTAWed joint, (c) friction stir-processed GTAWed joint, (d) unprocessed FSWed joint, and (e) friction stir-processed FSWed joint.

TABLE 5: Grain sizes measured.

\begin{tabular}{lccccc}
\hline \multirow{2}{*}{ Technique } & \multicolumn{2}{c}{ Diameter $(\mu \mathrm{m})$} & Mean values & Standard deviation \\
& 1 & 2 & 3 & 17.14 & 1.50 \\
Base & 18.63 & 15.63 & 9.20 & 8.657 & 0.362 \\
FSW & 8.57 & 8.20 & 4.68 & 4.62 & 0.127 \\
FSP-FSW & 4.74 & 4.44 & 11.08 & 10.78 & 0.249 \\
GTAW & 10.96 & 10.30 & 7.000 & 7.177 & 0.125 \\
FSP-GTAW & 7.010 & 7.520 & &
\end{tabular}

measurements were performed on the unprocessed GTAWed joint to determine the size of the porosities in Figure 7 (a) and were found to range from 11.24 to $20.46 \mu \mathrm{m}$.
The average grain size for TMAZ on friction stir-processed GTAWed (Figure 7(b)) was measured to be $8.06 \mu \mathrm{m}$ with columnar grains ranging from 40.60 to $83 \mu \mathrm{m}$ and the HAZ 


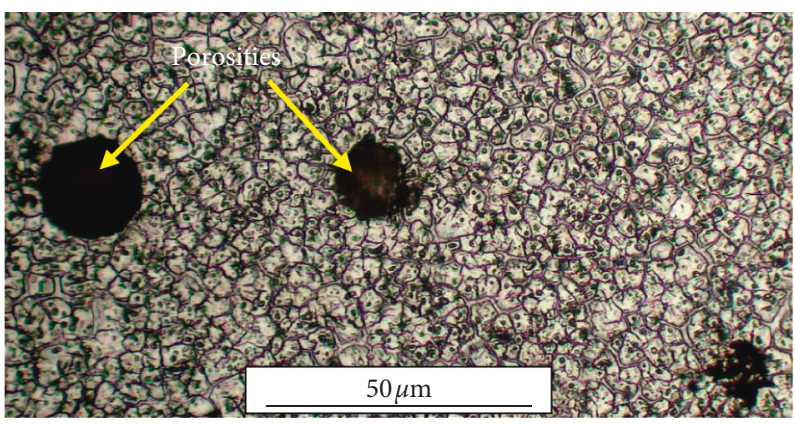

(a)

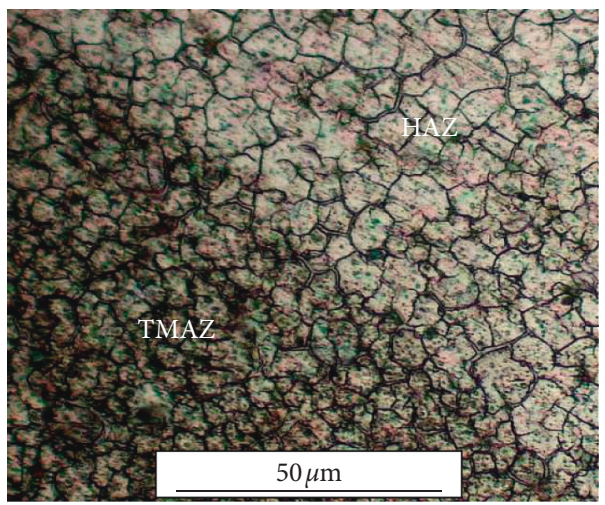

(c)

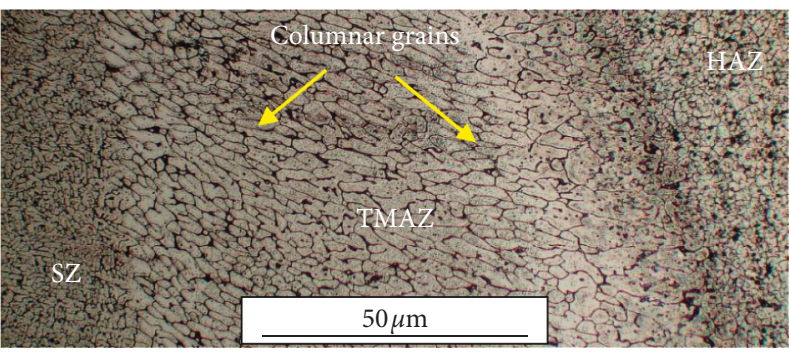

(b)

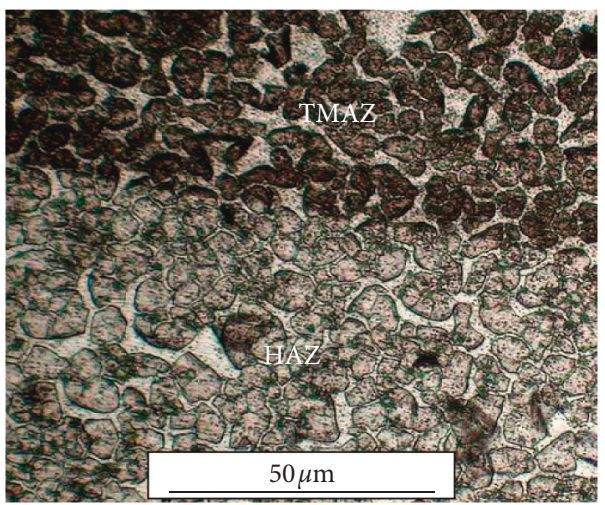

(d)

Figure 7: Optical micrographs of the TMAZ and HAZ regions at $50 \mu \mathrm{m}$ scale (objective 20x): (a) unprocessed GTAWed joint, (b) friction stir-processed GTAWd joint, (c) unprocessed FSWed joint, and (d) friction stir-processed FSWed joint.

with average grains of $9.99 \mu \mathrm{m}$. The average grains for TMAZ and HAZ for the unprocessed FSW (Figure 7(c)) were 9.36 and $11.56 \mu \mathrm{m}$, respectively. The friction stir-processed FSWed average grain size (Figure 7(d)) for TMAZ was 7.53 and $8.39 \mu \mathrm{m}$ for HAZ.

3.3. Microhardness Tests. Figure 8 illustrates Vicker's microhardness profiles for unprocessed and friction stirprocessed GTAWed and FSWed joints. There is a notable decrease in the microhardness value from the centre to either the advancing or retreating side of the stir zone. This behaviour is the same for processed and unprocessed FSWed joint. The processed GTAWed joint exhibits similar behaviour to processed and unprocessed FSWed. This behaviour is a result of the coarsening of the precipitates on the welded region formed during FSW process, as well as the reheating and restirring during FSP $[55,56]$. The unprocessed GTAWed joint shows an approximately horizontal line to the retreating side with a microhardness value of about $87 \mathrm{HV}$. Additionally, the microhardness profile for the GTAW is not symmetrical around the welds centreline. There is a notable decrease from the centre line to the retreating side. This is a very common behaviour when using the ER5356 filler which is most likely to be caused by the nonuniform melt flow field on both sides of the weld centre [57]. Chaurasia et al. [58] also reported a decrease in the microhardness as a result of little higher heat input in advancing than on the retreating side. There is a decrease in microhardness further away from the centre in both unprocessed and friction stir-processed GTAWed and FSWed joints, which is a result of the joints experiencing less strain and nonuniform grain structures. It was noted that the microhardness values of the processed and unprocessed joints (FSWed and GTAWed) were higher compared to the base metal one. This behaviour of microhardness is influenced by the change in grain sizes and grain distribution [59-61].

3.4. Tensile Tests. Table 6 shows the tensile test results for the friction stir-processed and unprocessed GTAWed joints. The notable trend shown in Table 3 is that the ultimate tensile strength (UTS) of the friction stir-processed specimens is higher than the unprocessed one. Moreover, the UTS for specimens cut at the beginning of the plate is lower than the UTS of the specimens cut in the middle and at the end of the plate. It is assumed that this trend emerges from the insufficient heat input occurring at the beginning of the welding or processing. A similar trend was also noted by Çevik [62]. It was also noted that the yield strength and the UTS for all the specimens (processed and unprocessed) were lower than those of the base metal. This is mainly due to the effect of heat input which does have an impact on the mechanical properties of the AA5083-H111 alloy [63]. Additionally, the AA5083-H111 base metal is a work hardened alloy in which the microstructure is highly unstable and has unequiaxed grain structures as seen in Figure 6(a); the application of FSW initiated a recrystallization due to high temperature during the process 


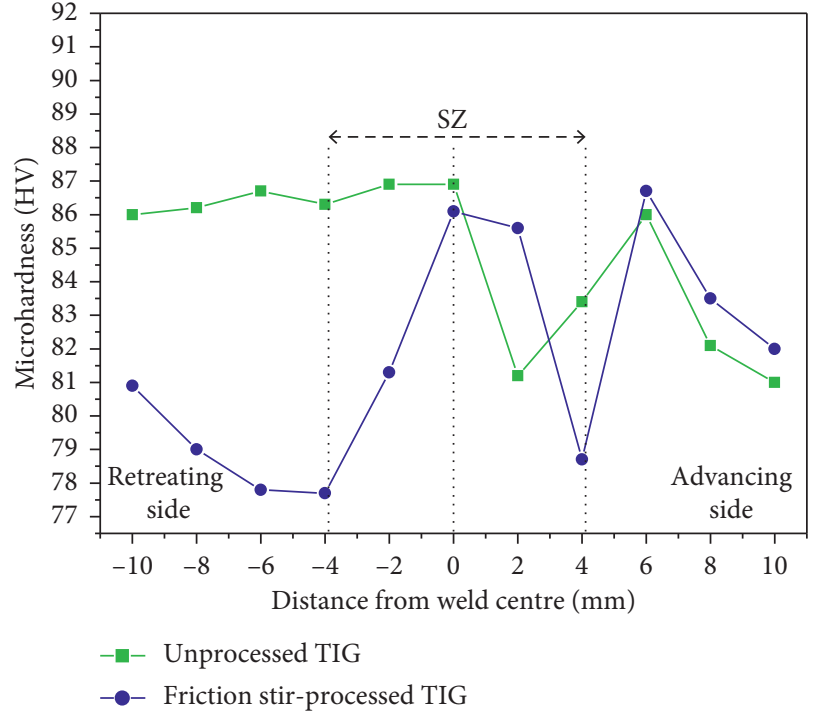

(a)

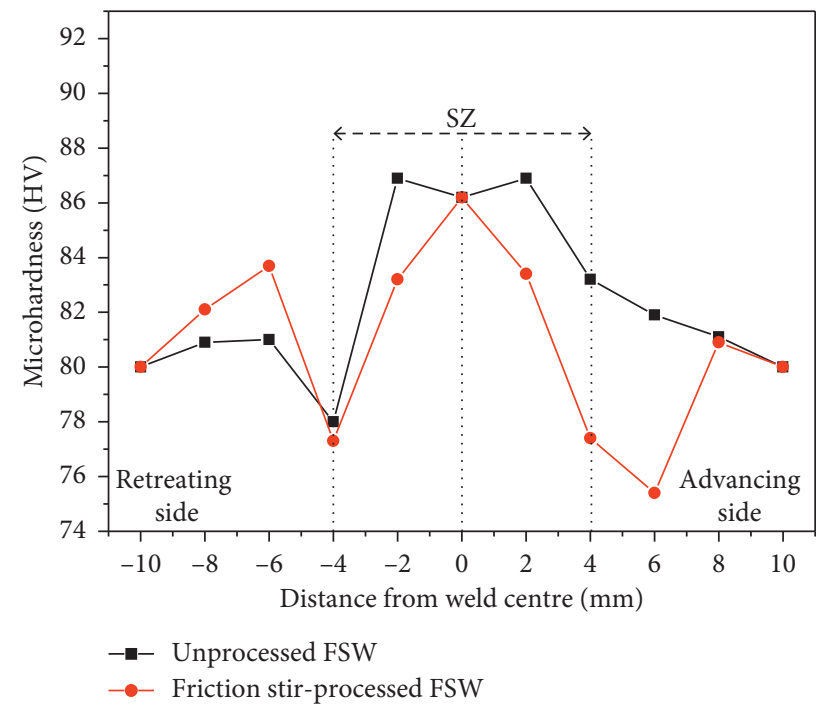

(b)

FIGURE 8: Microhardness graphs of the welded joints: (a) unprocessed and friction stir-processed GTAWed joint and (b) unprocessed and friction stir-processed FSWed joint.

TABLE 6: Friction stir-processed and unprocessed GTAW weld joints results.

\begin{tabular}{lcccc}
\hline Sample & $\mathrm{R} \rho 0.2$ yield strength $(\mathrm{MPa})$ & Ultimate tensile strength $(\mathrm{MPa})$ & Percentage elongation (\%) & Joint efficiency $(\%)$ \\
\hline Base metal & & 350 & 16 & 6.56 \\
A & 38.220 & 46.028 & 9.41 & 43.15 \\
B & 68.111 & 153.75 & 8.56 & 34 \\
C & 53.139 & 133.833 & 12 & 49.19 \\
A2 & 122.08 & 172.167 & 16 & 53.35 \\
B2 & 93.421 & 186.722 & 22.86 & 71.40 \\
C2 & 173.611 & 249.917 & & \\
\hline
\end{tabular}

destroying the work-hardened state and weakening the mechanical properties [61]. Then, the re-recrystallization that happens during the FSP application comes and remodifies the microstructure of the alloy strengthening the mechanical properties $[25,28,35]$.

Amongst the tensile properties is the joint efficiency which is a numerical value, which represents a percentage, expressed as the ratio of the strength of a riveted, welded, or brazed joint to the strength of the base material [25]. The joint efficiency was determined by dividing the UTS of the weld by that of the base material. The friction stir-processed GTAWed joint showed maximum joint efficiency of about $71.4 \%$ while the unprocessed one was found to be $44 \%$. There is also a notable improvement on the percentage elongation of the friction stir-processed joints compared to the unprocessed ones. This suggests that the ductility of the material has improved. The specimen C2 had highest percentage elongation compared to all specimens (base metal, unprocessed and other friction stir-processed specimens). Figure 9 shows the engineering stress and strain curves of the unprocessed and friction stir-processed GTAWed joints in correlation to Table 6. A similar impact of FSP on tensile properties of materials was also reported in the literature [24, 47, 64].
Table 7 and Figure 10 shows the tensile test results for the friction stir-processed and unprocessed FSWed joints. The trend noted with unprocessed and friction stir-processed GTAWed joint is also noticed with unprocessed and friction stir-processed FSWed results. The only difference is that the UTS and joint efficiency of the unprocessed FSWed joint were higher than those of the unprocessed GTAWed joint. Liu et al. [65] and Ceschini [66] obtained very similar behaviour of the tensile properties. The UTS of $303.153 \mathrm{MPa}$ and joint efficiency of $86.60 \%$ for the friction stir-processed FSWed joint shows a clear increment along the joint while the unprocessed shows some fluctuations. The main reason for the increase in tensile properties of the friction stirprocessed FSWed joints is that the joints were re-reheated and re-recrystallized using the same parameters used for welding to enhance the mechanical properties and refine grain sizes [44, 45, 67]. A similar behaviour was also reported on the study by Salman et al. [20].

3.5. Fracture Surface Morphology. Figure 11 reveals the SEM micrograph of fractured surface for the unprocessed and the friction stir-processed GTAWed and FSWed joint specimens. Figure 11(a) shows the fractured surface for the base 


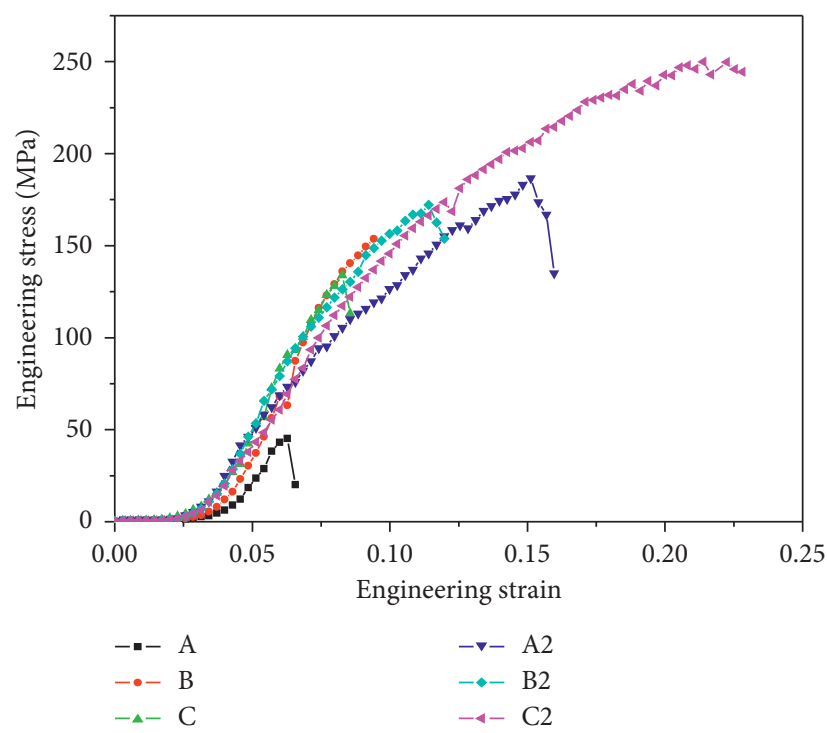

FIGURE 9: Engineering stress-strain curves of the unprocessed and friction stir-processed GTAW specimens.

TABLE 7: Friction stir-processed and unprocessed FSWed joints results.

\begin{tabular}{lcccc}
\hline Sample & $\mathrm{R} \rho 0.2$ yield strength $(\mathrm{MPa})$ & Ultimate tensile strength $(\mathrm{MPa})$ & Percentage elongation (\%) & Joint efficiency $(\%)$ \\
\hline Base metal & & 350 & 16 & 16.54 \\
A & 174.528 & 256.806 & 18.54 & 74.88 \\
B & 162.167 & 258.75 & 17.11 & 73.93 \\
C & 179.861 & 262.083 & 30.52 & 73.37 \\
A2 & 139.722 & 286.028 & 29.09 & 81.72 \\
B2 & 156.806 & 299.94 & 24.50 & 85.70 \\
C2 & 118.611 & 303.153 & 86.60 \\
\hline
\end{tabular}

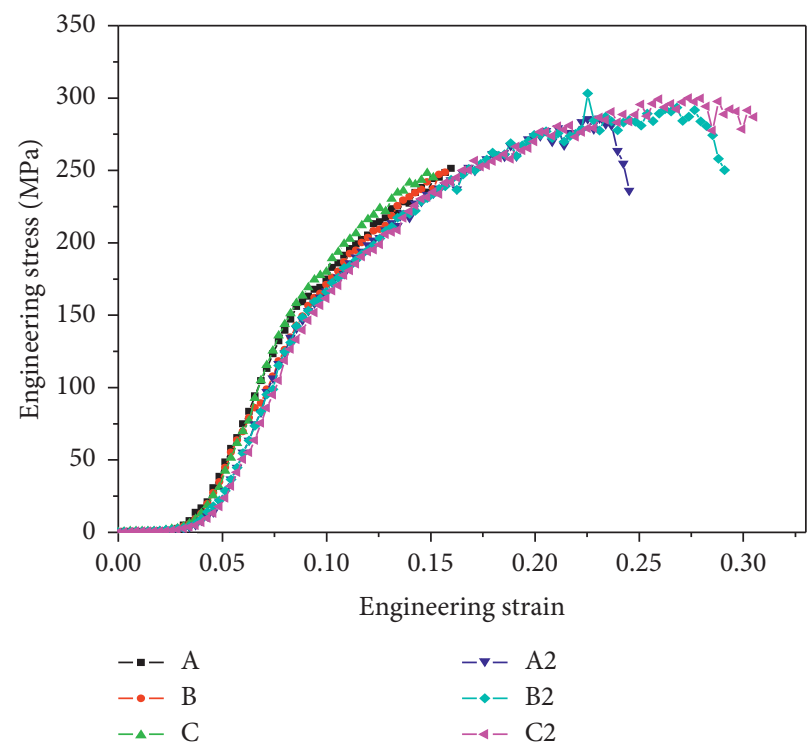

FIGURE 10: Engineering stress-strain curves of the unprocessed and friction stir-processed FSW specimens.

metal. The unprocessed GTAWed joint shown in Figure 11(b) reveals some rough fracture surface with some notable voids and cleavage facets which correlated with the microstructure results. This kind of observation suggests that the GTAWed joint had a brittle failure. Cleavage facets, dimples, and matrix cracks were noted on the surface of the other three fracture surfaces (see Figure 11(c)-11(e)). This then suggests a ductile failure of the unprocessed FSWed and 


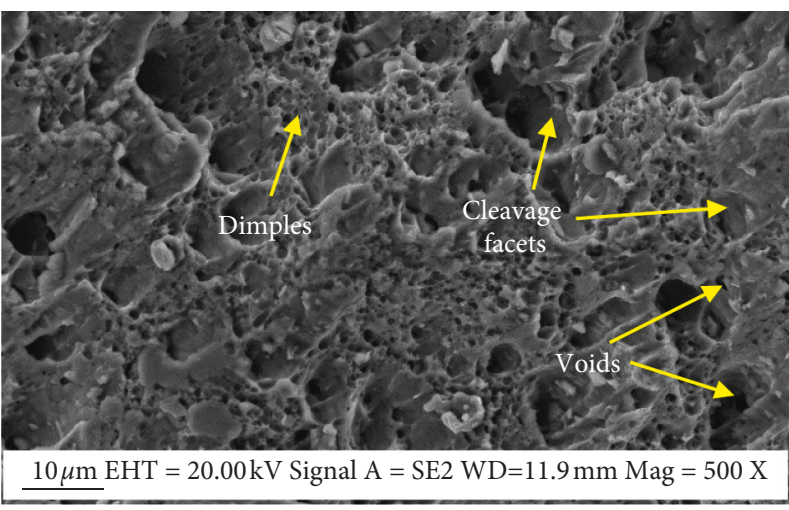

(a)

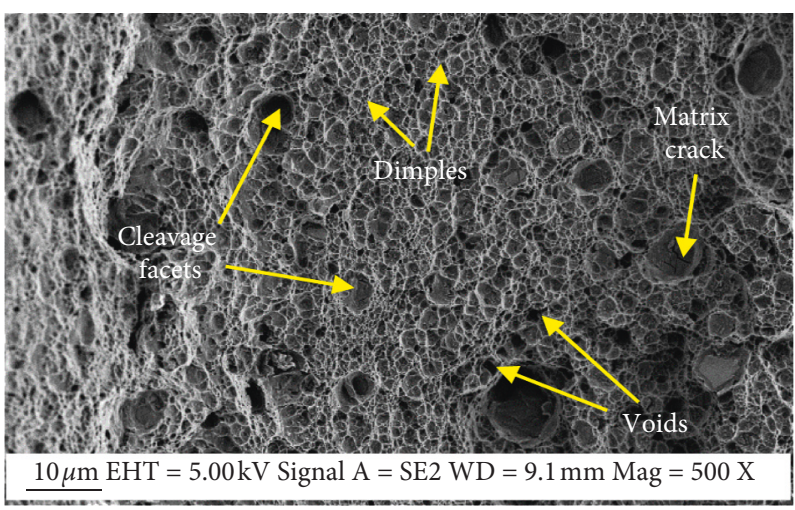

(c)

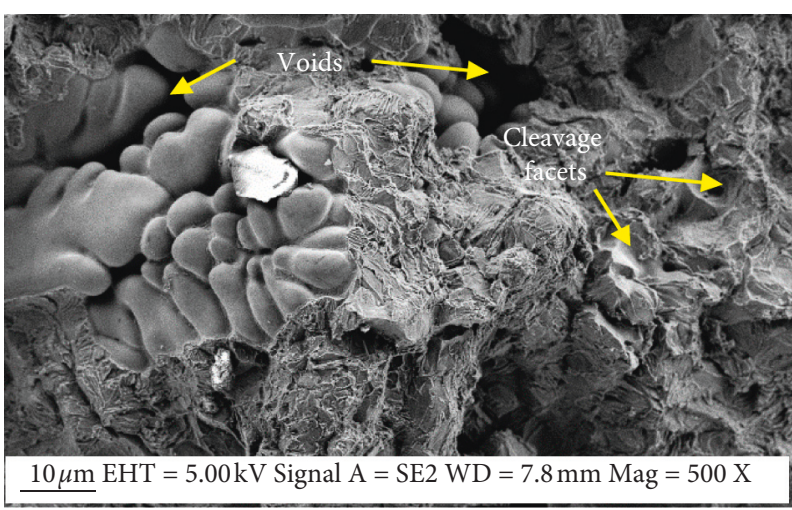

(b)

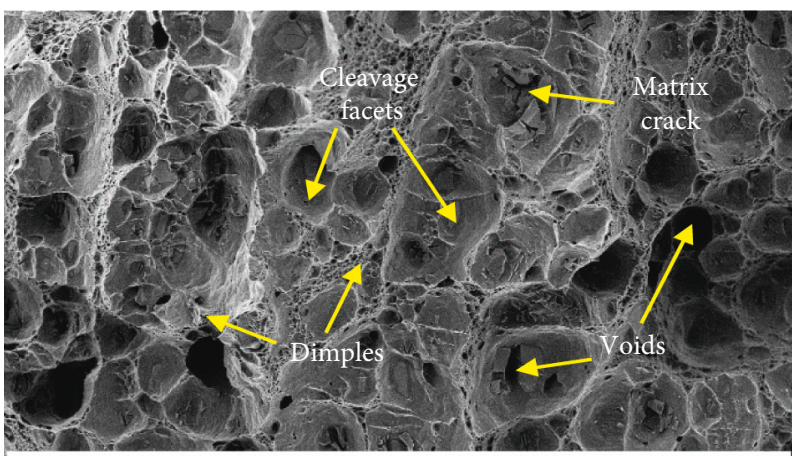

$10 \mu \mathrm{m}$ EHT $=5.00 \mathrm{kV}$ Signal A $=$ SE2 WD $=9.4 \mathrm{~mm} \mathrm{Mag}=500 \mathrm{X}$

(d)

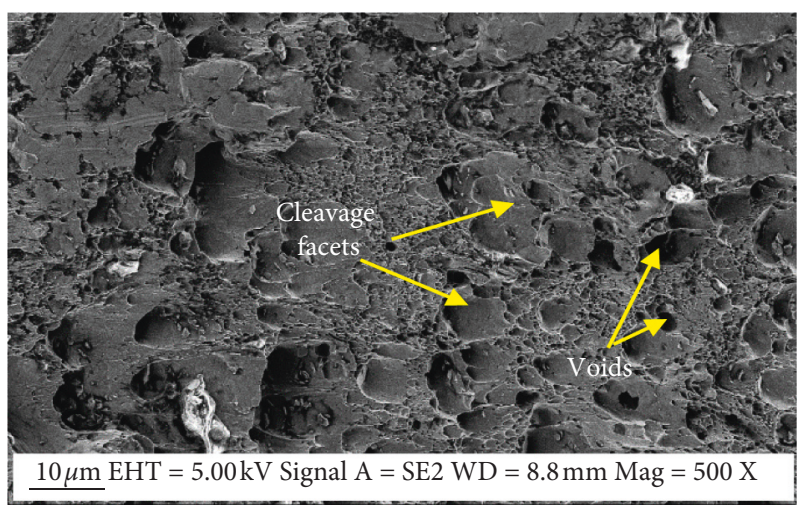

(e)

FIGURE 11: SEM photos: (a) base metal, (b) unprocessed GTAWed joint, (c) friction stir-processed GTAWed joint, (d) unprocessed FSWed joint, and (e) friction stir-processed FSWed joint.

friction stir-processed GTAWed and FSWed joints. The dimple sizes measured were ranging from 10.64 to $22.18 \mu \mathrm{m}$ for the unprocessed GTAWed fracture surface, while for the friction stir-processed GTAWed joints, the dimples ranged from 1.66 to $17.72 \mu \mathrm{m}$. The unprocessed FSWed joint dimples were found to be about 4.90 to $17.72 \mu \mathrm{m}$, and the friction stir-processed GTAWed joint ones were found to be ranging from 3.33 to $15.59 \mu \mathrm{m}$. The same ductile behaviour was obtained where the dimple of the fracture is obvious without the phenomenon of intergranular fracture [35, 68-70]. The friction stir-processed GTAWed and FSWed morphology showed a lot of dimples due to recrystallization and reheating of the joint which softened the material.

\section{Conclusions}

The analysis of the friction stir-processed and unprocessed GTAWed and FSWed joints were successfully fabricated and analyzed in this study. The main conclusions can be summarized as follows:

(i) The unprocessed GTAWed joint shows very low mechanical properties compared to the friction stir- 
processed GTAWed joint. The mechanical properties of the GTAWed joint improved after it has been friction stir processed. Similar behaviour is also observed with friction stir-processed and unprocessed FSWed joints. Maximum tensile properties obtained were found on the friction stirprocessed FSWed specimen $\mathrm{C}$. The best results were a UTS of $303.153 \mathrm{MPa}$, yield strength of 118.611 MPa, percentage elongation of $24 \%$, and a joint efficiency of $86.6 \%$.

(ii) The application of FSP also improved the ductility of the welded joints, with friction stir-processed FSWed joint being more ductile in comparison to the friction stir-processed GTAWed ones. The ductility is correlated by the surface morphology results where the friction stir-processed FSWed results revealed best reduced dimple sizes.

(iii) The macroscopic and microscopic results have shown that FSP technique can be used as a weld joint enhancement technique. The reheating and restirring in the stir zone resulted in significant improvement of the mechanical and microstructural properties of the processed joints. The distinctive grain size refinement occurred in both friction stir-processed FSWed and GTAWed joints. However, the friction stir-processed FSWed joints had the greatest refinement due to the severe rereheating, re-restirring, and re-recrystallization experienced during FSP.

(iv) The microhardness of the unprocessed and friction stir-processed joints was marginally affected by the friction stir processing technique giving maximum microhardness of $87 \mathrm{HV}$.

\section{Data Availability}

The authors would like to confirm that the data generated during the study is available and can be accessed on request.

\section{Conflicts of Interest}

The authors declare that there are no conflicts of interest that may arise from this work.

\section{Acknowledgments}

The authors are grateful to the Mechanical Engineering Workshop staff, especially Ms. Molebogeng Segaetsho, Ms. Shaheeda Petersen, and Mr. Malwande Masekwana.

\section{References}

[1] N. Sun and D. Apelian, "Microstructural modification of A206 aluminium via friction stir processing," Materials Science Forum, vol. 618-619, pp. 361-364, 2009.

[2] T. R. McNelley, "Friction stir processing (FSP): refining microstructures and improving properties," Revista de Metalurgia, vol. 46, pp. 149-156, 2011.
[3] A. R. Kumar, S. Varghese, and M. Sivapragash, "A comparative study of the mechanical properties of single and double sided friction stir welded aluminium joints," Procedia Engineering, vol. 38, pp. 3951-3961, 2012.

[4] G. E. Totten and D. S. Mackenzie, Handbook of Aluminum, Volume 1: Physical Metallurgy and Processes, Marcel Dekker, New York, NY, USA, 1st edition, 2003.

[5] G. Çam, V. Ventzke, J. F. dos Santos et al., "Characterization of laser and electron beam welded Al-alloys," Praktische Metallographie, vol. 36, no. 2, pp. 59-89, 1999.

[6] G. Çam, V. Ventzke, J. F. Dos Santos, M. Koçak, G. Jennequin, and P. Gonthier-Maurin, "Characterisation of electron beam welded aluminium alloys," Science and Technology of Welding and Joining, vol. 4, no. 5, pp. 317-323, 1999.

[7] G. İpekoğlu, B. Gören Kıral, S. Erim, and G. Çam, "Investigation of the effect of temper condition friction stir weldability of AA7075 Al-alloy plates," Materials and Technology, vol. 46, no. 6, pp. 627-632, 2012.

[8] G. Çam, G. İ.t Ava, and H. Tarık Serindağ, "Effects of use of higher strength interlayer and external cooling on properties of friction stir welded AA6061-T6 joints," Science and Technology of Welding and Joining, vol. 19, no. 8, pp. 715-720, 2014.

[9] G. Çam, S. Güçlüer, A. Çakan, and H. T. Serindag, "Mechanical properties of friction stir butt-welded Al-5086 H32 plate," Materialwissenschaft und Werkstofftechnik, vol. 40, no. 8, pp. 638-642, 2009.

[10] Z. Y. Ma, "Friction stir processing technology: a review," Metallurgical and Materials Transactions A, vol. 39, no. 3, pp. 642-658, 2008.

[11] N. Kashaev, V. Ventzke, and G. Çam, "Prospects of laser beam welding and friction stir welding processes for aluminum airframe structural applications," Journal of Manufacturing Processes, vol. 36, pp. 571-600, 2018.

[12] G. Çam and G. İpekoğlu, "Recent developments in joining of aluminium alloys," The International Journal of Advanced Manufacturing Technology, vol. 91, no. 5-8, pp. 1851-1866, 2017.

[13] G. Çam, "Friction stir welded structural materials: beyond AlAlloys," International Materials Reviews, vol. 56, no. 1, pp. 1-48, 2011.

[14] G. Ípekoğlu, S. Erim, and G. Çam, "Investigation into the influence of post-weld heat treatment on the friction stir welded AA6061 Al-Alloy plates with different temper conditions," Metallurgical and Materials Transactions A, vol. 45, no. 2, pp. 864-877, 2014.

[15] G. İpekoğlu, S. Erim, B. Gören Kıral, and G. Çam, "Investigation into the effect of temper condition on friction stir weldability of AA6061 Al-alloy plates," Kovove Mater, vol. 51, no. 3, pp. 155-163, 2013.

[16] G. İpekoğlu and G. Çam, "Effects of initial temper condition and postweld heat treatment on the properties of dissimilar friction-stir-welded joints between AA7075 and AA6061 aluminum alloys," Metallurgical and Materials Transactions A, vol. 45, no. 7, pp. 3074-3087, 2014.

[17] F. Nascimento, T. Santos, P. Vilaça, R. M. Miranda, and L. Quintino, "Microstructural modification and ductility enhancement of surfaces modified by FSP in aluminium alloys," Materials Science and Engineering: A, vol. 506, no. 1-2, pp. 16-22, 2009.

[18] L. Karthikeyan, V. S. Senthilkumar, V. Balasubramanian, and S. Natarajan, "Mechanical property and microstructural changes during friction stir processing of cast aluminum 2285 alloy," Materials \& Design, vol. 30, no. 6, pp. 2237-2242, 2009. 
[19] F. Y. Zheng, Y. J. Wu, L. M. Peng, X. W. Li, P. H. Fu, and W. J. Ding, "Microstructures and mechanical properties of friction stir processed $\mathrm{Mg}-2.0 \mathrm{Nd}-0.3 \mathrm{Zn}-1.0 \mathrm{Zr}$ magnesium alloy," Journal of Magnesium and Alloys, vol. 1, no. 2, pp. 122-127, 2013.

[20] A. A. Salman, A. M. Takak, and K. K. Resan, "Enhancements of mechanical properties of friction stir welding for 6061 aluminium alloy by FSP method," Basrah Journal for Engineering Science, vol. 14, pp. 62-66, 2014.

[21] R. Sathiskumar, N. Murugan, I. Dinaharan, and S. J. Vijay, "Characterization of boron carbide particulate reinforced in situ copper surface composites synthesized using friction stir processing," Materials Characterization, vol. 84, pp. 16-27, 2013.

[22] M. S. Węglowski, "Friction stir processing-state of the art," Archives of Civil and Mechanical Engineering, vol. 18, no. 1, pp. 114-129, 2018.

[23] R. Senthilkumar, M. Prakash, N. Arun, and A. A. Jeyakumar, "The effect of the number of passes in friction stir processing of aluminum alloy (AA6082) and its failure analysis," Applied Surface Science, vol. 491, pp. 420-431, 2019.

[24] S. H. Aldajah, O. O. Ajayi, G. R. Fenske, and S. David, "Effect of friction stir processing on the tribological performance of high carbon steel," Wear, vol. 267, no. 1-4, pp. 350-355, 2009.

[25] H. Zhao, Q. Pan, Q. Qin, Y. Wu, and X. Su, "Effect of the processing parameters of friction stir processing on the microstructure and mechanical properties of 6063 aluminum alloy," Materials Science and Engineering: A, vol. 751, pp. 70-79, 2019.

[26] J. K. Paik, "Mechanical properties of friction stir welded aluminum alloys 5083 and 5383," International Journal of Naval Architecture and Ocean Engineering, vol. 1, no. 1, pp. 39-49, 2009.

[27] B. Zahmatkesh, M. H. Enayati, and F. Karimzadeh, "Tribological and microstructural evaluation of friction stir processed Al2024 alloy," Materials \& Design, vol. 31, no. 10, pp. 4891-4896, 2010.

[28] R. S. Mishra, M. W. Mahoney, S. X. McFadden, N. A. Mara, and A. K. Mukherjee, "High strain rate superplasticity in a friction stir processed $7075 \mathrm{Al}$ alloy," Scripta Materialia, vol. 42, no. 2, pp. 163-168, 1999.

[29] N. Sun and D. Apelian, "Friction stir processing of aluminum cast alloys for high performance applications," Jom, vol. 63, no. 11, pp. 44-50, 2011.

[30] N. Sun, W. J. Jones, and D. Apelian, "Friction stir processing of aluminum alloy A206: part II-tensile and fatigue properties," International Journal of Metalcasting, vol. 13, no. 2, pp. 244-254, 2019.

[31] S. Chainarong, P. Muangjunburee, and S. Suthummanon, "Friction stir processing of SSM356 aluminium alloy," Procedia Engineering, vol. 97, pp. 732-740, 2014.

[32] K. N. Ramesh, S. Pradeep, and V. Pancholi, "Multipass friction-stir processing and its effect on mechanical properties of aluminum alloy 5086," Metallurgical and Materials Transactions A, vol. 43, no. 11, pp. 4311-4319, 2012.

[33] S. S. Abdulmalik, R. Ahmad, and O. Y. Usman, "Microstructure and tensile properties of friction stir processed Al-Si alloy," Saudi Journal of Engineering and Technology, vol. 3, no. 9, pp. 593-597, 2018.

[34] K. B. Golafshani, S. Nourouzi, and H. Jamshidi Aval, "Evaluating the microstructure and mechanical properties of friction stir processed Al-Si alloy," Materials Science and Technology, vol. 35, no. 9, pp. 1061-1070, 2019.
[35] N. Saini, C. Pandey, S. Thapliya, and D. K. Dwivedi, "Mechanical properties and wear behavior of $\mathrm{Zn}$ and $\mathrm{MoS}_{2}$ reinforced surface composite Al- Si alloys using friction stir processing," Silicon, vol. 10, no. 5, pp. 1979-1990, 2018.

[36] K. Devireddy, V. Devuri, M. Cheepu, and B. K. Kumar, "Analysis of the influence of friction stir processing on gas tungsten arc welding of 2024 aluminum alloy weld zone," International Journal of Mechanical and Production Engineering Research and Development, vol. 8, no. 1, pp. 243-252, 2018.

[37] K. Elangovan and V. Balasubramanian, "Influences of tool pin profile and tool shoulder diameter on the formation of friction stir processing zone in AA6061 aluminium alloy," Materials \& Design, vol. 29, no. 2, pp. 362-373, 2008.

[38] J. Gandra, R. Miranda, P. Vilaça, A. Velhinho, and J. P. Teixeira, "Functionally graded materials produced by friction stir processing," Journal of Materials Processing Technology, vol. 211, no. 11, pp. 1659-1668, 2011.

[39] H. M. A. Kumar, V. V. Ramana, and M. Pawar, "Experimental study on dissimilar friction stir welding of aluminium alloys (5083-H111 and 6082-T6) to investigate the mechanical properties," IOP Conference Series: Materials Science and Engineering, vol. 330, Article ID 012076, 2018.

[40] J. J. S. Dilip, M. Koilraj, V. Sundareswaran, G. D. Janaki Ram, and S. R. Koteswara Rao, "Microstructural characterization of dissimilar friction stir welds between AA2219 and AA5083," Transactions of the Indian Institute of Metals, vol. 63, no. 4, pp. 757-764, 2010.

[41] Y. Chen, H. Wang, X. Wang et al., "Influence of tool pin eccentricity on microstructural evolution and mechanical properties of friction stir processed Al-5052 alloy," Materials Science and Engineering: A, vol. 739, pp. 272-276, 2019.

[42] G. Singh, A. S. Kang, K. Singh, and J. Singh, "Experimental comparison of friction stir welding and TIG welding process for 6082-T6 aluminium alloy," Materials Today: Proceedings, vol. 4, no. 2, pp. 3590-3600, 2017.

[43] R. S. Mishra and Z. Y. Ma, "Friction stir welding and processing," Materials Science and Engineering: R: Reports, vol. 50, no. 1-2, pp. 1-78, 2005.

[44] V. Sharma, U. Prakash, and B. V. M. Kumar, "Surface composites by friction stir processing: a review," Journal of Materials Processing Technology, vol. 224, pp. 117-134, 2015.

[45] R. Abrahams, J. Mikhail, and P. Fasihi, "Effect of friction stir process parameters on the mechanical properties of 5005-H34 and 7075-T651 aluminium alloys," Materials Science and Engineering: A, vol. 751, pp. 363-373, 2019.

[46] K. N. Krishnan, "On the formation of onion rings in friction stir welds," Materials Science and Engineering: A, vol. 327, no. 2, pp. 246-251, 2002.

[47] G. R. Cui, Z. Y. Ma, and S. X. Li, "Periodical plastic flow pattern in friction stir processed Al-Mg alloy," Scripta Materialia, vol. 58, no. 12, pp. 1082-1085, 2008.

[48] B. Yang, J. Yan, M. A. Sutton, and A. P. Reynolds, "Banded microstructure in AA2024-T351 and AA2524-T351 aluminum friction stir welds," Materials Science and Engineering: $A$, vol. 364, no. 1-2, pp. 55-65, 2004.

[49] A. Abdolahzadeh, H. Omidvar, M. A. Safarkhanian, and M. Bahrami, "Studying microstructure and mechanical properties of SiC-incorporated AZ31 joints fabricated through FSW: the effects of rotational and traveling speeds," The International Journal of Advanced Manufacturing Technology, vol. 75, no. 5-8, pp. 1189-1196, 2014. 
[50] R. H. Stevens, ASM Handbook Metallography and Microstructures, Vol. 9, ASM International, Cleveland, OH, USA, 2000.

[51] V. Subramani, B. Jayavel, R. Sengottuvelu, and P. J. L. Lazar, "Assessment of microstructure and mechanical properties of stir zone seam of friction stir welded magnesium AZ31B through nano-SiC," Materials, vol. 12, no. 7, p. 1044, 2019.

[52] E. Taban and E. Kaluc, "Microstructural and mechanical properties of double-sided MIG, TIG and friction stir welded 5083-H321 aluminium alloy," Kovove Mater, vol. 44, pp. 25-33, 2006.

[53] C. G. Prosgolitis, S. G. Lambrakos, and A. D. Zervaki, "Phasefield modeling of nugget zone for a AZ31-Mg-alloy friction stir weld," Journal of Materials Engineering and Performance, vol. 27, no. 10, pp. 5102-5113, 2018.

[54] M. Bahrami, K. Dehghani, and M. K. Besharati Givi, "A novel approach to develop aluminum matrix nano-composite employing friction stir welding technique," Materials \& Design, vol. 53, pp. 217-225, 2014.

[55] M. Momeni and M. Guillot, "Post-weld heat treatment effects on mechanical properties and microstructure of AA6061-T6 butt joints made by friction stir welding at right angle (RAFSW)," Journal of Manufacturing and Materials Processing, vol. 3, no. 2, p. 42, 2019.

[56] H. Jamshidi Aval and S. Serajzadeh, "A study on natural aging behavior and mechanical properties of friction stir-welded AA6061-T6 plates," The International Journal of Advanced Manufacturing Technology, vol. 71, no. 5-8, pp. 933-941, 2014.

[57] A. Ramarajan and K. Subbaiah, "Effect of heat transfer in tungsten inert gas welding of 5000 series aluminium alloys," Journal of Chemical and Pharmaceutical Sciences, vol. 7, pp. 214-217, 2017.

[58] P. K. Chaurasia, C. Pandey, A. Giri, N. Saini, and M. M. Mahapatra, "A Comparative study of residual stress and mechanical properties for FSW and TIG weld on structural steel," Archives of Metallurgy and Materials, vol. 63, no. 2, pp. 1019-1029, 2018.

[59] W. Hussein and M. A. Al-Shammari, "Fatigue and fracture behaviours of FSW and FSP joints of AA5083-H111 aluminium alloy," IOP Conference Series: Materials Science and Engineering, vol. 454, Article ID 012055, 2018.

[60] A. Devaraju and V. Kishan, "Influence of cryogenic cooling (liquid nitrogen) on microstructure and mechanical properties of friction stir welded 2014-T6 aluminum alloy," Materials Today: Proceedings, vol. 5, no. 1, pp. 1585-1590, 2018.

[61] M. Peel, A. Steuwer, M. Preuss, and P. J. Withers, "Microstructure, mechanical properties and residual stresses as a function of welding speed in aluminium AA5083 friction stir welds," Acta Materialia, vol. 51, no. 16, pp. 4791-4801, 2003.

[62] B. Çevik, "Analysis of welding groove configurations on strength of S275 structural steel welded by FCAW," Journal of Polytechnic, vol. 21, no. 2, pp. 489-495, 2018.

[63] G. Peng, Y. Ma, J. Hu et al., "Nanoindentation hardness distribution and strain field and fracture evolution in dissimilar friction stir-welded AA 6061-AA 5A06 aluminum alloy joints," Advances in Materials Science and Engineering, vol. 2018, Article ID 4873571, 11 pages, 2018.

[64] M. Balakrishnan, I. Dinaharan, R. Palanivel, and R. Sathiskumar, "Effect of friction stir processing on microstructure and tensile behavior of $\mathrm{AA} 6061 / \mathrm{Al}_{3} \mathrm{Fe}$ cast aluminum matrix composites," Journal of Alloys and Compounds, vol. 785, pp. 531-541, 2019.
[65] H. J. Liu, H. Fujii, M. Maeda, and K. Nogi, "Friction stir welding of AA5083 aluminum alloy," Transactions of Nonferrous Metals Society of China, vol. 13, pp. 14-17, 2003.

[66] L. Ceschini, I. Borome, G. Mina, A. Morria, and F. Tarterini, "Effect of friction stir welding on microstructure, tensile and fatigue properties of the AA7005/10 vol. $\% \mathrm{Al}_{2} \mathrm{O}_{3 p}$ composite," Composites Science and Technology, vol. 67, no. 3-4, pp. 605-615, 2007.

[67] N. Saini, C. Pandey, and D. Kumar Dwivedi, "Ductilizing of cast hypereutectic $\mathrm{Al}-17 \% \mathrm{Si}$ alloy by friction stir processing," Proceedings of the Institution of Mechanical Engineers, Part E: Journal of Process Mechanical Engineering, vol. 232, no. 6, pp. 696-701, 2018.

[68] C. Pandey and M. M. Mahapatra, "Effect of groove design and post-weld heat treatment on microstructure and mechanical properties of P91 steel weld," Journal of Materials Engineering and Performance, vol. 25, no. 7, pp. 2761-2775, 2016.

[69] C. Pandey, N. Saini, M. M. Mahapatra, and P. Kumar, "Study of the fracture surface morphology of impact and tensile tested cast and forged (C\&F) Grade 91 steel at room temperature for different heat treatment regimes," Engineering Failure Analysis, vol. 71, pp. 131-147, 2017.

[70] C. Pandey, M. M. Mahapatra, P. Kumar et al., "Study on effect of double austenitization treatment on fracture morphology tensile tested nuclear grade P92 steel," Engineering Failure Analysis, vol. 96, pp. 158-167, 2019. 


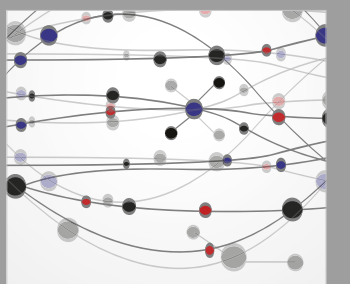

The Scientific World Journal
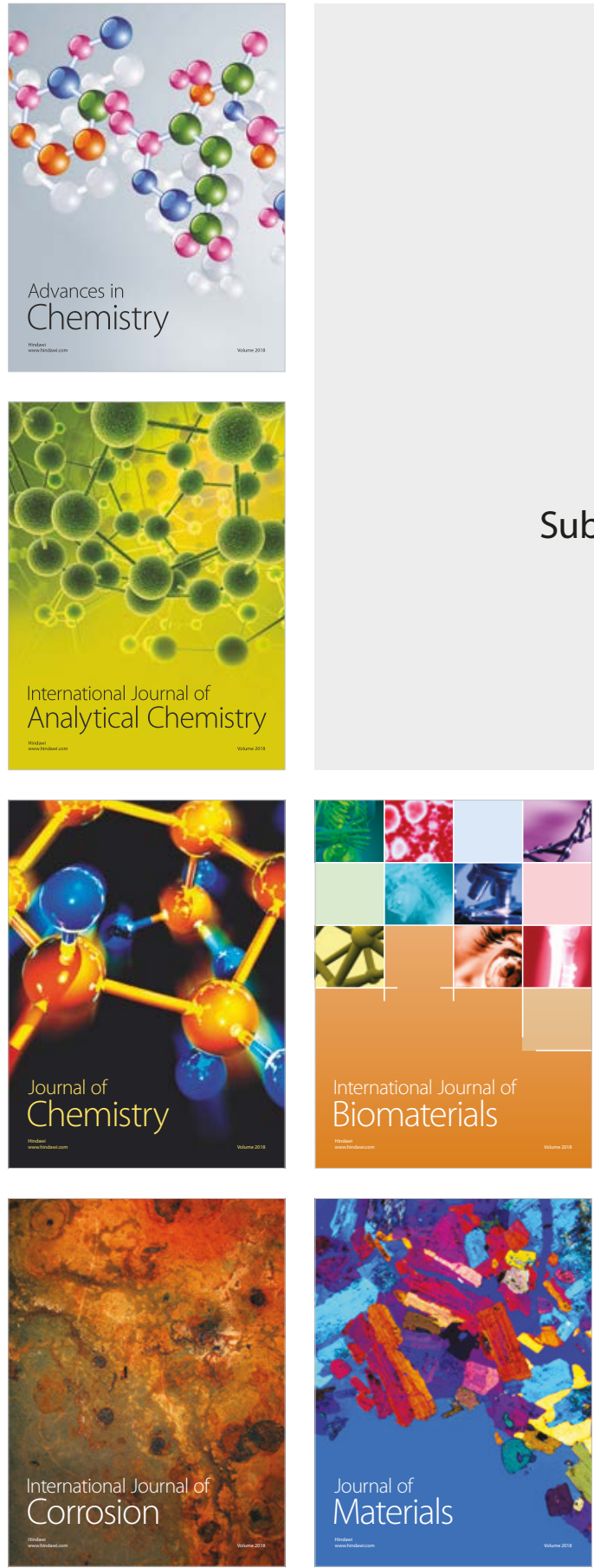

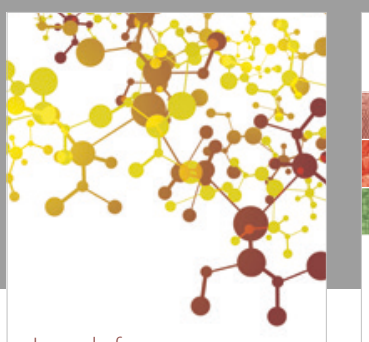

Journal of

Applied Chemistry
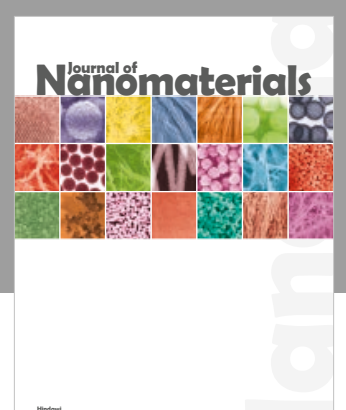

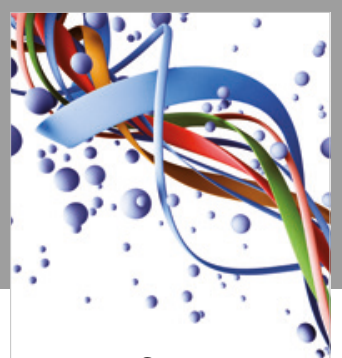

Scientifica

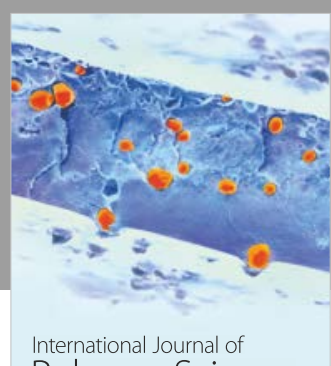

Polymer Science

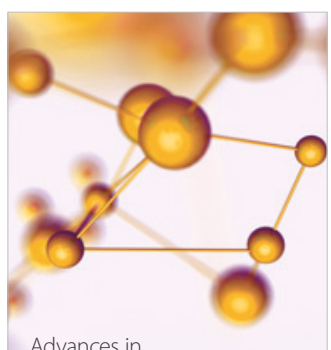

Physical Chemistry
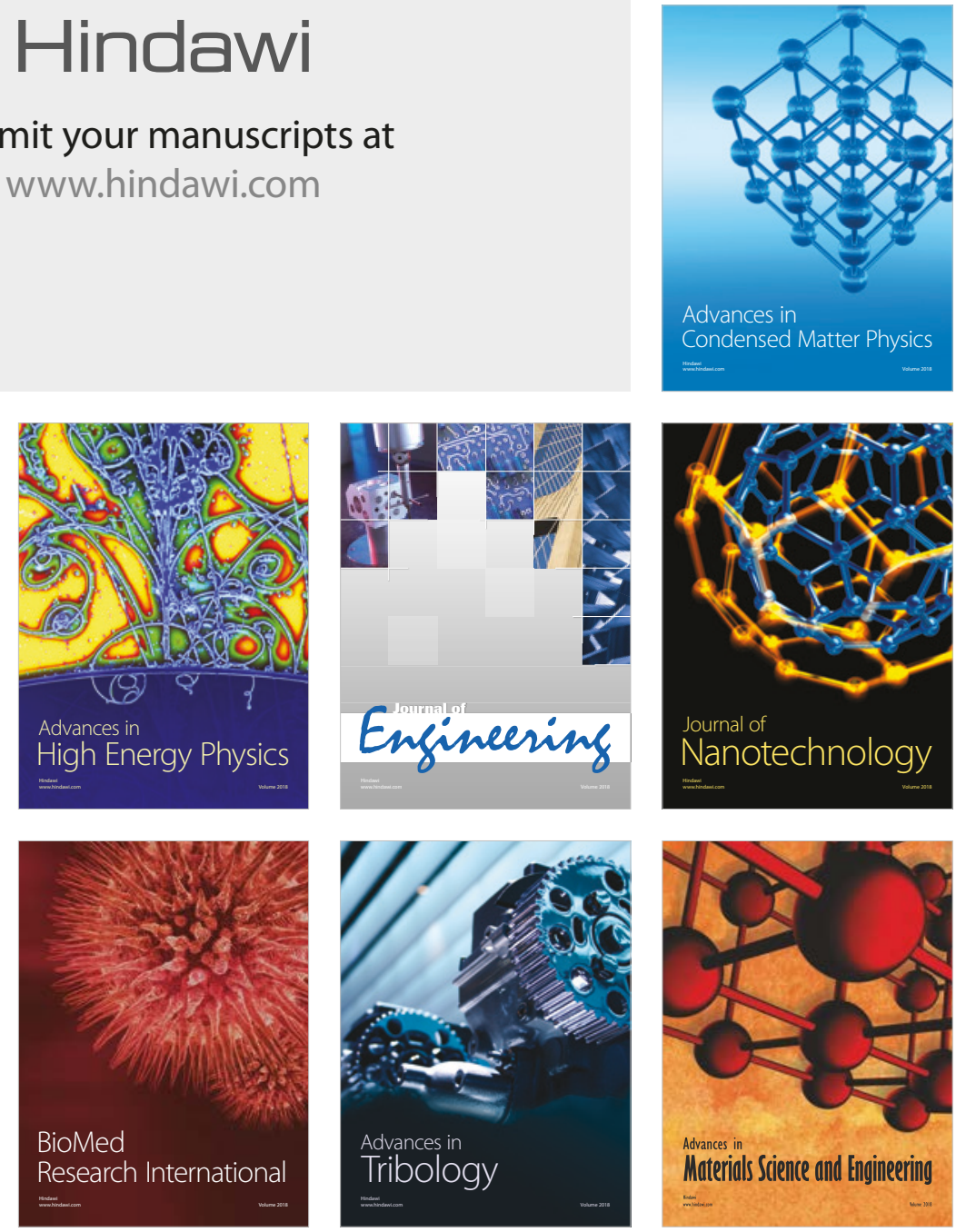